Published in Canadian Review of American Studies 45.1 (2015): 83-100.

\title{
Concord Companions: Margaret Fuller, Friendship and Desire
}

\author{
Robert K. Martin and Justin D. Edwards ${ }^{1}$
}

The language of Friendship is not words but meanings.

--Thoreau, "Friendship"

In this paper we examine the rhetoric of friendship and desire in mid nineteenthcentury American writing. We begin by looking at Waldo Emerson's essay on friendship and Henry David Thoreau's poem "Sympathy" (1840) to provide a context for reading Margaret Fuller's fascinating texts on same-sex bonds between women. Of particular interest to us is Fuller's translation of Elizabeth von Arnim's Die Günderode (1840), a collection of letters between Arnim and the German Romantic poet Karoline von Günderode which provides compelling insights into the early to mid nineteenth-century continuum between female friendship and same-sex desire. In our analysis, we situate this translation alongside Fuller's own female friendships and expressions of love for women, more specifically her declarations of love to Anna Barker and, later, to George

\footnotetext{
${ }^{1}$ In 2003, Robert and I began co-writing a book on female-masculinity and male-femininity in 19thcentury U.S. literature. This project was drafted but never completed - in part, because of distance (Robert in Montreal; me in Copenhagen), and in part because of the tragic advance of Robert's illness. But before time and space overcame the project, we completed a chapter on Margaret Fuller, which I have revised, edited and updated for publication in this special issue.
} 
Sand. This latter relationship, we suggest, was a source of admiration and anxiety, for Sand's cross-dressing and fluid sense of gender identity was simultaneously celebrated and condemned in Fuller's Women in the Nineteenth Century (1843). Thus, we see both of these documents - Fuller's translation of Die Günderode and her portrait of Sand - as complicating the conventional notion that expressions of love between women of the nineteenth century did not pose a challenge to compulsory heterosexuality.

\section{Friendship in Concord}

Friendship in Concord, Massachusetts was obviously a privileged subject, as many documents including Emerson's and Thoreau's essays and Thoreau's poem "Sympathy" attest. But the celebration of friendship, however much located in a discourse of Platonic or Romantic idealism, always ran the risk of spilling over into something else, something less elevated or elevating. The advocates of Transcendental friendship were living at a time when friendship itself was becoming suspicious: anxieties regarding same-sexuality grew out of discourses that constructed homosexual subjectivity and disseminated homosexual panic through the demonization of the homosexuality as an illness or a deformed "species." To understand some of these tensions, which have repercussions in Nathaniel Hawthorne's novels - particularly The Blithedale Romance (1852) and The Marble Faun (1860) - we would like to start with a little incident, recounted (inaccurately) by Edward Havilland Miller in his biography of Hawthorne. Miller reports that in 1842 Charles King Newcomb sent Hawthorne "an inscribed copy of his translation of Elizabeth von Arnim's Die Günderode", a work that "records in evasive nineteenth-century sentimental prose an unsatisfying friendship between two young 
women who fumble toward a satisfaction that society denied" (194-5). Miller's term "evasive" needs to be examined more closely here, for it presupposes a consciousness and a vocabulary that were not available to Arnim, or, possibly, her translator.

It is extremely useful, nonetheless, to have Miller recall this incident and remind us of Newcomb. Newcomb's relationship to the community at Brook Farm is an underdeveloped area of research, and further analysis of his considerable journals and erotic poems may shed light on the multiple contexts (philosophical, religious, and sexual) of the utopian community. But Miller gets it slightly wrong: the translation of Die Günderode that Newcomb sent Hawthorne is by Margaret Fuller. Indeed, Fuller had long been interested in Arnim's text so it is entirely appropriate that Fuller should translate this crucial study of female Romantic friendship, and also appropriate that Hawthorne might not have been pleased by the gift; after all, the gift did not come from the translator herself but from an ardent young man, who possibly saw a parallel between the women's friendship in the text and a relationship that he sought with Hawthorne (or other men). In any case, Hawthorne refused Fuller's request that Newcomb come to stay with the Hawthornes.

We seek to examine this episode in terms of its possibilities. First, it is possible that Fuller engaged in the translation of Die Günderode as a way of expressing her own desire and longing for a close bond with another woman. Second, it is possible that Newcomb's identification with Fuller is marked by his yearning for "Romantic friendship" and not as a potential suitor, as he has been portrayed in the orthodoxy of American literary criticism. Third, it is possible that the gift and Hawthorne's negative response to Newcomb reflects his conflicted position - his attraction to and repulsion 
from - the idea of intense same-sex friendship, even in its Platonic form. These possibilities must be placed in the context of the celebration of romantic friendships in turn-of-the century Germany, and the anxieties that this celebration provokes as it moves across the Atlantic later in the $19^{\text {th }}$ century. For if in a period of German romanticism, Günderode stands for an "innocent" love, she becomes supplanted later in the $19^{\text {th }}$ century by a potentially more threatening figure in European literature, George Sand. Indeed, Fuller's attempt to relate to Sand in her life and writing reflects her valiant attempt to walk a fine line between sympathy and social censure.

Two of the central texts on friendship in Concord illustrate the dual conceptual origins of same-sex relationships - Platonism and German Romanticism - and some of the limitations that arise out of these influences. In Emerson's 1839 essay on friendship, we find some of the personal coldness which Stephen Whicher refers to as "his craving for friendship and love", a craving which "seldom found adequate satisfaction" as "invisible repulsions usually constrained him to awkwardness and aloofness with other men and denied his wish for companionship or adequate overt expression" (63). In place of the personal friendship he desired, Emerson turns to the Platonic contemplation of the ideal, even concluding his essay by directly quoting and paraphrasing the Phaedrus: "True love transcends the unworthy object and dwells and broods on the eternal" (236). Here, we find an evasion of the textual source and, by extension, Emerson denies its context in the expression of love for embodied beauty in the form of a young man, as well as the sense of repulsion, that would prompt Walt Whitman's revision of these lines, his refusal of the "unworth[iness]" of the object of desire. 
Throughout the essay, Emerson denies the pleasures of the body. This extraordinary resistance to physical desire is most clearly expressed in his assertion that it is difficult to "establish it [friendship] with flesh and blood" (234). Yet in this protest this language of corporeal repulsion - there is also a strong counter-discourse, for friendship in Emerson's essay is explicitly masculine. This is significant in that the model of friendship in European Romanticism allowed for friendship both across and within the sexes, but Emerson moves toward a parallel construction of "Love and Friendship" between men, a same-sex bond that culminates in Whitman's models of Amativeness and Adhesiveness, and which was played out later in the century in the medicalized discourses separating heterosexuality from homosexuality. In fact, Emerson's language surrounding the relations between male friends is virtually Foucauldian: the bond, he writes, "piques each [friend] with the presence of power and consent in the other party", allowing for a dance of uncertainty and control that cannot be found in the unequal terms of heterosexual relations. The true friend must, for Emerson, show "a manly furtherance or at least a manly resistance" and not "a mush of concession" (232). Similarly, in a fascinating sequence of thought that strikingly anticipates Whitmanian Adhesiveness, he makes the following statement: "I hate the prostitution of the name of friendship to signify modish and worldly alliances. I much prefer the company of ploughboys and tinpeddlers to the silken and perfumed amity which celebrates its days of encounter by a frivolous display" (230). The ploughboy is unprostituted and unperfumed, an unalloyed masculinity that is the worthy object of desire.

Tensions and conflicts are threaded throughout Emerson's essay. But an early metaphor in the text stands in for Emerson's self-contradictory terms and the meanings 
he simultaneously evades and reveals. Defining friendship as a "select and sacred relation which is a kind of absolute" and "even leaves the language of love suspicious and common" - a kind of love "passing the love of women" - Emerson establishes his ideal, pure relation, and he goes on to represent the encounter of a friend in sincerity and simplicity. "I am arrived at last in the presence of a man", he writes, "so real and equal that I may drop even those undermost garments of dissimulation, courtesy, and second thought, which men never put off' (228). Here, another source for Whitman is revealed: in this case, the language of nudity is invoked as a revelation of true selfhood. Yet Emerson's representation of the encounter of the two naked men is astonishing in its directness: his friend is a man who makes him take off his underwear. Once again, we see the tensions that run throughout Emerson's text; on the one hand, he seeks a "pure" love that is, in a Platonic sense, devoid of the body but, on the other hand, the revealing of the naked body - in all its physicality - is invoked in the language and imagery of an ideal friendship. This illustrates the elaborate minuet of body and soul that is enacted throughout Emerson's writing, particularly when he turns to the subject of male friendship. What is also remarkable in this passage is the way in which the context of the late 1830s allowed Emerson to use these metaphors when describing same-sex bonds. That which would become unutterable in the late nineteenth-century (the love that dare not speak its name) is utterable in 1839 , a period prior to the formative discourse of sexuality and "perversion" that, by making male/male desire visible, made it unspeakable.

Another significant source for exploring friendship in Concord is Henry David Thoreau's poem, “Sympathy”, which was written the same year as Emerson's essay. 
Here, Thoreau's images and metaphors, as well as the language he uses, evoke a similar set of conventions that are found in Emerson's essay. The poem, which was apparently prompted by Thoreau's love for the 11-year old Edmund Sewell, begins with an allusion to Shakespeare's Sonnet 20:

Lately, alas, I knew a gentle boy, Whose features all were cast in Virtue's mould, As one she had designed for Beauty's toy, But after manned him for her own stronghold.

In this extract, the final line includes a wordplay that conjures up the androgynous figure of the "gentle boy" - a crucial figure in Hawthorne's writing - but it also insists on the phallocentricism of the body. For while his manliness offers him the stronghold of Virtue, the gender the speaker's object of desire also raises vital questions about the speaker's affections. This questioning and provokes a sense of doubt that is most clearly expressed when the speaker states, "I might have loved him, had I loved him less". Here, the sense of doubt may suggest personal and social problems: personally, the speaker drives away the beloved by displaying too much desire; socially, it is clear that only a "less[er]" love between a man and a boy is permissible. As in Emerson's text, the tensions here are particularly striking. For although Thoreau begins with a bawdy reference to Shakespeare's sonnets to help situate his speaker's expressions of love, he then turns to the model of the pastoral elegy as a way of celebrating love after death (or, in this case, the departure of the loved one). From this perspective, "Lycidas" is evoked 
in lines such as "Make haste and celebrate my tragedy; / With fitting strain resound, ye woods and fields" and this moves toward the consolation of the poem: the true spirit of the love is preserved, even as the object of love has departed. This forms an Emersonian conclusion to the poem (and reminds us of lines from Tennyson's "In Memoriam", written at approximately the same time). Like Hallam, Edmund is represented as moving away from the physicality of the human condition as he becomes part of the natural landscape: "If I but love that virtue which he is / Though it be scented in the morning air, / Still shall we be truest acquaintances". Here, Thoreau seeks to move from the particular friend to the Platonic friend or the ideal friendship, a shift that echoes Emerson by simultaneously containing and eliding the physical expression of love with which the poem somewhat nervously began.

Is a sexual reading of these texts appropriate? Given that these works are published prior to late nineteenth-century definitions of sexual identity, can we approach these texts from a sexualized perspective? There is no doubt that a certain "innocence" makes Thoreau's poem publishable in the first issue of The Dial; it would have been unpublishable later in the century. Yet the poem is situated - like Emerson's essay and his dropped underpants - at the very heart of Transcendentalist literature, philosophy and culture. Rather than dismissing same-sexuality in these texts because, in the Foucauldian sense, the homosexual had not been "invented", it is more productive to examine how these texts are able to represent love between men precisely because such relationships could not be understood as homosexuality. In this, expressions of same-sex bonds were not regulated or policed within the discourses of sexual categories or sexual identities. This is not to adopt an ahistorical approach to the texts. Instead, it is a call to avoid the 
assumption that because there was no concept of homosexuality in 1839 it is not possible to read these texts from the perspective of the sexual. In other words, if the category of homosexuality does not exist 1839 , then neither does heterosexuality.

\section{Fuller's Die Günderode}

Margaret Fuller, editor of The Dial for the first two years of its publication, was at the heart of the Concord circle, and she contributed to its discourse of intense friendship. But Fuller's model of romantic friendship was not as tied to Platonism as it was for her male counterparts. Instead, she drew on her knowledge and understanding of German Romanticism and her awareness that deep female friendship could be harnessed as a social and political force to resist the powerful forces of patriarchy. In fact, Fuller's attraction to German Romanticism was, in part, based on what Edith Toegel calls the "valuing of women's talent" while remaining "intellectually respectful of their feminine difference" (145). Fuller's own friendships were exceptionally intense. One of the participants in her famous "Conversations", for instance, recalls the following experience: "one day when she was alone with me, and I feel as if I could now feel her touch and hear her voice, she said, 'Is life rich to you?' and I replied, 'It is since I have known you"' (quoted in Chevigny 230). During her years in the United States, Fuller's closest friendships were with Anna Barker and Caroline Sturgis. In fact, Anna Barker's marriage in 1840 was a great blow to Fuller; years later she would recall her love for Barker in language that echoes the words of Goethe: "we have been so little together, all was from the elective affinities. But still I love her with a sort of pallid, tender romance, $\&$ feel towards her as I can to no other woman". Fuller's account of this love is both 
rapturous and at least officially located in an ideal realm. She begins by asserting the legitimacy of her affections and justifying her relationship: "It is so true that a woman may be in love with a woman and a man with a man." This leads her to reflect on the historical and idealized justification for same-sex relations, and then she proceeds to recall her friendship with Anna Barker:

I loved [Anna] for a time with as much passion as I was then strong enough to feel. Her face was always gleaming before me, her voice was always echoing in my ear, all poetic thoughts clustered round the dear image. This love was for me a key which unlocked many a treasure which I still possess; it was the carbuncle (emblematic gem!) which cast light into many of the darkest caverns of human nature. (quoted in Chevigny 112-3)

The literary critic Mason Wade omitted the last sentence of this passage in his quotation from this journal entry. He then goes on to read the truncated quotation in the following way: "there was an undercurrent of homosexuality in [such affairs], though they were harmlessly platonic. Margaret's masculinized personality tended to attract her to girls instead of to the opposite sex, particularly when they possessed the beauty and feminine charm which she wholly lacked" (90). Such assumptions - indeed, such homophobia are present throughout early Fuller criticism, but Wade's reading is particularly conspicuous, especially when he concludes by asserting that "such sentiments and experiences [...] long prevented her from fulfilling the true nature of a woman. It is doubtful whether she fully realized this twist in her nature before her marriage" (90-1). 
It is tempting to read Wade's conclusion as a popular Freudian strand of mid twentieth-century literary criticism. But to do so would be to neglect other documents from Fuller's contemporaries - documents that echo Wade's highly problematic conclusions. We might recall, for instance, Sophia Hawthorne's reaction to Fuller's “The Great Lawsuit": "It seems to me", states Sophia Hawthorne, "that if she [Fuller] were married truly, she would no longer be puzzled about the rights of woman. This is the revelation of woman's true destiny and place, which never can be imagined by those who do not experience the relation. [...] Home I think is the great arena for women" (quoted in Chevigny 231-2). And if Sophia Hawthorne thought Fuller should put aside the rights of women for marriage, then her husband judged Fuller even more harshly. In The Blithedale Romance he portrays her as Zenobia and, in so doing, he calls attention to the dangerous possibilities of intense female friendships and erotic attractions between women. Here, the domestication of Priscilla and the violent death of Zenobia warn the reader against such bonds. But although Hawthorne attempts to erase loving same-sex relations from the plot, with its final resolution of the "mystery" of the relation of the two women (later revealed to be half-sisters), the text only partially undoes the powerful erotics of the first encounter of the two women. "She stood near the door", relates the narrator, "fixing a pair of large, brown, melancholy eyes upon Zenobia, -- only upon Zenobia! -- she evidently saw nothing else in the room, save that bright, fair, rosy, beautiful woman. It was the strangest look I ever witnessed; long a mystery to me, and forever a memory" (454).

The expression of physical attraction conveyed in this queer look foreshadows Coverdale's observation in the following chapter. Here, he voices some of the anxieties 
that were provoked by the intense same-sex bonds that Fuller both aroused and defended in her writings. According to Coverdale,

\begin{abstract}
A brilliant woman is often an object of the devoted admiration - it might almost be termed worship, or idolatry - of some young girl. [...] We men are too gross to comprehend it. Even a woman, of mature age, despises or laughs at such a passion. There occurred to me no mode of accounting for Priscilla's behavior, except for supposing that she had read some of Zenobia's stories (as such literature goes everywhere), or her tracts in defense of the sex, and had come hither with the one purpose of being her slave. (457)
\end{abstract}

This passage is crucial. It gives expression to Hawthorne's anxieties about same-sex relations, as well as his deeply troubled response to intellectual women. But perhaps more importantly it is also the spark that inspires Henry James to rewrite an explicitly lesbian version of the same narrative in The Bostonians (1886). This is not to suggest that a clear sense of lesbian identity was being articulated in these texts, but the so-called "vice of Lesbos" was recognized, even (and notably) in Fourierist texts, and the social construction of same-sexuality between women as a transgression was underway.

How did Fuller respond to the negative discourses surrounding intense female friendships and calls for her to simply get married? One of her responses is articulated through her translation of Die Günderode, Bettina von Arnim's collection of letters between herself and her close friend, the German Romantic poet Karoline von Günderode. Female friendship appealed to Fuller in part because it held the potential for 
a symmetrical relationship that was uncorrupted by the patriarchal power dynamics inherent to male-female relations. In her introduction to various sections of the correspondence, Fuller is critical of Arnim for acting as a slave to Goethe in her earlier book, Goethes Briefwechsel mit einem Kind, and although Fuller did not complete the translation, her introduction to the work appeared in the January 1842 edition of The Dial, and was published alongside a selection of Elizabeth Peabody's letters from the same year. Today the canon of European Romanticism is only beginning to recognise the significance of Günderode's work, and this is largely through the remarkable efforts of Christa Wolf, the German feminist critic, who has written several essays on Günderode and edited a collection of her work. Thus, we seek to draw on Wolf's assessment as a partial guide to Günderode and to the significance she had for Fuller.

Wolf sees Günderode and the other women of the German Romantic period as the "first women intellectuals", daughters of the utopian moment of the French Revolution who had lived through the loss of liberation in their own lives, and had been forced to return to bourgeois values and conventions of pre-Revolutionary Europe. Fuller, too, was one of the first American women intellectuals, closely connected to Emerson, Channing, and Hawthorne, and yet never allowed to realize the potential of the Transcendental or Fourierist moment. A daughter of a more revolutionary generation, Fuller lived through the crucial years of the 1830 s in which the sense of possibility for women was being radically reduced, and the cult of bourgeois domesticity was being firmly cemented. For Wolf, Günderode's life was partly defined by her "need to love" and her "inability to live the life of a middle-class woman", an apparent contradiction that is reflected in Fuller's own life choices, and to Hawthorne's mockeries of her in The Blithedale Romance (32- 
3). Wolf argues that Günderode's love for Bettina von Arnim is linked to her "pride, her love of freedom; the radicalism of her thought and of her hopes; the embodiment of a utopia" (33). There is personal love, certainly, but it is intimately connected to a social commitment and a political sense of self, which include the need for self-expression, creative space and freedom from domesticity.

There are other reasons why Fuller was drawn to translating Die Günderode. She was, for instance, sympathetic to the desires, needs and ultimately the failure of Karoline von Günderode. Arnim's book, published in 1840, long after Günderode's death in 1806, conveys a tragic note by gesturing toward the possibilities of Günderode's contribution to Romanticism and the limitations that were imposed on her. The letters, then, are significant documents for understanding the reality of this situation and, in Wolf's terms, it is a truly authentic book, even if the documents themselves are frequently rearranged in their details. Indeed, Wolf sees Arnim as responding to a poetic and a political need far more important than formal rules of textual attribution: it is a book of letters, lacking form, but written from experience, and full of feeling. The book is, according to Wolf, a principle "witness to a friendship between two women, but also a document of forms of life and customs and a critique of those customs, which does not hesitate to go to the roots" (29). The two women give voice not only to their love for each other but also their desire to not live through men, a desire that cannot be fulfilled in the world they inhabit. This is expressed in a letter Karoline wrote to another friend: "Why was I not a man?", she asks, "I have no disposition to womanly virtues, to womanly bliss. Only the wild, the large, the glorious pleases me" (quoted in Wolf 5). For Wolf, Günderode's sense of frustration increased as she realised that, in her lifetime, women would be excluded from 
male power and authority, even after they had glimpsed the new possibilities promised in the French Revolution. Wolf, though, also acknowledges that Günderode would have been subject to the accusation of being "unnatural" had her inclinations been known, and there is evidence to suggest that she did suffer from such allegations (and that Arnim later tried to deflect them). Was Margaret Fuller subject to such accusations? Certainly the portrayal of Zenobia and the remarks regarding strong women in The Blithedale Romance, along with the urgency of insisting on her marriage, suggest that she too suffered from this kind of defamation.

Karoline von Günderode's life came to a sad end. The exact details are unclear. Wolf offers a heterocentric version that corresponds to her reading of the intense female friendship as social and political, not physically passionate or expressions of sexual desire. Wolf asserts that Günderode had fallen deeply in love with a married man who was unable to fulfil her desires. Lacking an independent income, she saw no future for herself and, rejected by her lover, she killed herself on the edge of the Rhine, a dagger thrust into her heart. Other sources suggest that there was a quarrel between Arnim and Günderode over the man's assumption of his rights over Karoline. Whatever the case may be, we know that her body was, like Zenobia's, found by a farmer, partially submerged underwater, and that Günderode manuscripts were entrusted to her lover; these were suppressed by him, and her letters were burnt. Margaret Fuller seems in part to have accepted a view that placed emphasis on the relationship between Günderode and Arnim, and she is hard on the "eccentric and undignified old woman" Arnim became (quoted in Higginson 192). But as Christina Zwarg has shown, Fuller did not want to accept a "tragic" vision of the Romantic figure, a tragedy that would be akin to like that 
the dying native peoples of North America. For a "tragic" reading of Günderode's suicide would (as with Zenobia's) “destroy the efficacy of [her model of pedagogy and] obscure the radicalizing tendencies of her relationship with Arnim" (617). Günderode's fate includes an eerie resemblance to that of Margaret Fuller: Fuller described Günderode's end as death by drowning, and that she throws herself into the river because the world is too narrow. The legacy of Fuller's life and writing was edited by Emerson and her family, with much material suppressed or destroyed, and a career almost entirely silenced, or "transcendentalized", for close to a hundred years.

\section{Margaret Fuller and George Sand}

If, for Fuller, the Günderode-Arnim relationship offered a model for the intense same-sex friendship she desired throughout her life, then the figure of George Sand provided a particular fascination and allure. Sand held such appeal because she could openly cross-dress, declare her love for a young actress and smoke cigars in public. Assuming the liberties of her aristocratic privilege and her revolutionary sympathies (during a period when liberties were being curtailed), she was seen by her contemporaries as eccentric - not perverse or deviant - and, in certain quarters, she was titillating and charismatic.

There were of course practical reasons for why Aurore Dudevant chose to adopt a masculine pseudonym. It was a linguistic and identificatory gesture that freed her from a sense of gender that she did not recognise, and she began, like the Brontës, by seeking a name that was sexually undetermined - G. Sand. It is significant, then, that she began signing her personal letters "George" (normally using the English spelling rather than the 
French - yet another form of self fashioning) when she was writing to her friend Marie Dorval. Still, there is nothing in those letters, or in the diary accounts she kept, that would indicate any sense of shame or the need for secrecy when Sand expresses her love. For instance, in one passage, Sand recounts a fantasized account of waiting for Marie, and she states the following:

Ange silencieux, mettez votre main fraîche sur mon épaule, elle est chaude d'amour, mais aucun homme n'y a posé sa bouche; votre haleine parfumée, vos cheveux humides peuvent seuls la rafraîchir. Quelles fleurs avez-vous sur le front et dans les mains? Des fleurs inconnues, de fleurs plus belles qu'aucune femme de la terre. Ces parfums sont enivrants, mon ange, répandez-les sur moi, effeuillez sur moi votre couronne humide.

Mon ange, c'est assez. Je mourrais. Je veux vivre demain et vous revoir. Adieu, le jour grandit, partez vite, mon tresor, que personne ne vous voie, car on vous volerait à moi et je serais obligée de me donner aux hommes. Adieu, laissemoi baiser ton cou de neige et ton front où brille une étoile, donne-moi une plume de ton aile pour que je garde une preuve de ton passage, un souvenir de mon ivresse. (Quoted in Barry 156)

This document openly expresses the love and physical desire Sand felt for Marie Dorval. But if she fears that Marie may be stolen, and hence she left to men, she also conveys a generalized sense of sexuality without a fixed object. What is telling about such a document is the equanimity with which such love between women is regarded. 
During the mid- $19^{\text {th }}$ century, this expression of love - as well as Sand's public (masculinized) performance - did not fuel a sense of homosexual panic. This would arise later in the century. For Fuller, writing in the 1840s, Sand is championed as a woman of passion, an independent woman, who is unblemished by the contamination of what would later creep into the stories of Sand's alleged transgressions. In Woman in the Nineteenth Century (1845), for example, Fuller writes that "women like Sand will speak now and cannot be silenced; their characters and their eloquence alike foretell an era when such as they shall easier learn to lead true lives" (77). Fuller proclaims with pride that "George Sand smokes, wears male attire, wishes to be addressed as "Mon frère", that "Mignon and Theresa [in Wilhelm Meister] wear male attire when they like, and it is graceful for them to do so", and, even more boldly, that "there is no wholly masculine man, no purely feminine woman" $(75,129,116)$. This admiration of Sand motivated her determination to visit the Frenchwoman on her arrival in France. Several attempts were necessary, despite a letter of introduction from Mazzini, but finally the two women met:

Our eyes met. I shall never forget her look at that moment. The doorway made a frame for her figure; she is large, but well-formed. She was dressed in a robe of dark violet silk, with a black mantle on her shoulders, her beautiful hair dressed with the greatest taste, her whole appearance and attitude, in its simple and ladylike dignity, presenting an almost ludicrous contrast to the vulgar caricature idea of George Sand. [...] As our eyes met, she said "C'est vous," and held out her hand [...] we sat down a moment and then I said, "Il me fait de bien de vous voir," and I am sure I said it with my whole heart for it made me very happy to see such 
a woman, so large and so developed a character, and everything that is good in it so really good. I loved, shall always love her. (Quoted in Chevigny 361)

In this private letter, Sand does not arouse anxiety, only ardent sympathy. Indeed, Fuller expresses not only her delight in meeting this women, but also the admiration and love she holds for Sand with her "whole heart". Publically, though, Fuller felt the need to moderate her feelings for Sand. In a significant passage from Women in the Nineteenth Century, she asserts that Sand allows herself to be consumed by the wild heat of passion: "Those who would reform the world", writes Fuller, "must show that they do not speak in the heat of wild impulse; their lives must be unstained by passionate error; they must be severe lawgivers to themselves" (77). Here, Fuller speaks from her Transcendentalist position and anticipates her audience, even though she has tried to distinguish her own voice from Emerson's language of purity by commenting that "Cold bathing and exercise will not suffice to keep a life pure" (139).

But more is at stake here. For Sand invokes the possibility of overwhelming passion, not just in Fuller's private expressions of love, but also in the more general image of Sand has a figure who is motivated by "wild impulse" or "passionate error". This passage is one that Hawthorne clearly refers to in his anguished appraisal of Fuller, and he adapts it in The Scarlet Letter when the narrator comments (apparently reflecting Hester's views) that a "fallen woman" cannot be the prophetess of a new future because she is "stained with sin, bowed down with shame", while "the angel and apostle of the coming revelation must be a woman indeed, but lofty, pure, and beautiful; and wise, moreover, not through dusky grief but the ethereal medium of joy" (274). In light of such discourses, Fuller's praise of Sand comes with her acknowledgement that "George Sand 
would trample on every decorum, and every human law", even if this is in the name of "a sincere life" (149). Fuller no doubt acted wisely in concealing her admiration for Sand. For despite these obfuscations, Hawthorne still returns to the figure of Fuller as an ominous sign of female independence and female friendship. His accounts in his novels, and their rewriting in Henry James, have become the received figures of the feminist as threatening gendered and sexual conventions, indicating the hostile environment in which such women would seek to make sense of their desires.

Fuller's account of her love for women arises in the context of a generalization of possibility. Her exposure to Emerson's and Thoreau's writing about friendship between men - idealistic, Platonic, non-physical - inspired her to seek models in European Romanticism that would accommodate same-sex friendship between woman that was not simply based on the Transcendentalist principles that negated deep passion and intense desire. By invoking her friendship with Anna Barker and asserting that a woman may be in love with a woman, Fuller articulates a bond between women that is akin to heteronormative relations. This is not to reclaim Fuller as a lesbian writer, nor is it a challenge to Foucault's social constructionist model of hetero- and homosexual identities in the late nineteenth-century. Rather, it is a reflection on the mid nineteenth-century continuum of same-sex relations with the awareness that such a continuum is always precarious.

Works Cited 
Barry, Joseph. George Sand ou le scandale de la liberté. Paris: Seuil, 1982.

Chevigny, Bell Gale. The Woman and the Myth: Margaret Fuller's Life and Writings. Old Westbury: Feminist Press, 1976.

Emerson, Ralph Waldo. Selected Writings of Emerson. Ed. Brooks Atkinson. New York: Modern Library, 1950.

Fuller, Margaret. "Bettine Brentano and Günderode". The Dial 2 (January 1842): 313356.

- - - Women in the Nineteenth Century. 1845. New York: Norton, 1998.

Hawthorne, Nathaniel. Blithedale Romance and Fanshawe. Centenary Edition of the Works of Nathaniel Hawthorne. Ed. William Charvat, Roy Harvey Pearce, Claude M. Simpson. Vol 3. Columbus: Ohio State University Press, 1974.

- - - The Scarlet Letter. The Centenary Edition of the Works of Nathaniel Hawthorne. Ed. William Charvat, Roy Harvey Pearce, Claude M. Simpson. Vol. 1. Columbus: Ohio State University Press, 1974.

Higginson, Thomas Wentworth. Margaret Fuller Ossoli. 1890. New York: Greenwood Press, 1968. 
Miller, Edwin Haviland. Salem Is My Dwelling Place: A Life of Nathaniel Hawthorne. Iowa City: Iowa University Press, 1991.

Eve Kosofsky Sedgwick, Between Men: English Literature and Male Homosocial Desire. New York: Columbia University Press, 1985.

Thoreau, Henry David. Essays, Journals, and Poems. Ed. Dean Flower. Greenwich: Fawcett, 1975.

Toegel, Edith. “Margaret Fuller, Bettina von Arnim, Karoline von Gündderode: A Kinship of Souls”. Yearbook of German-American Studies 23 (1988): 141-151.

Wade, Mason. Margaret Fuller: Whetstone of Genius. New York: Viking, 1940.

Whicher, Stephen E. Freedom and Fate: An Inner Life of Ralph Waldo Emerson. 1953. New York: A. S. Barnes, 1961.

Wolf, Christa. Ed. Karoline von Günderrode. Der Schatten eines Traumes. Hamburg: Luchterhand, 1981.

Zwarg, Christina. "Footnoting the Sublime: Margaret Fuller on Black Hawk's Trail". ALH 5 (Winter 1993): 616-642. 
